\title{
Snowmelt lysimeters in the evaluation of snowmelt models
}

\author{
RighaRd KattelmanN \\ Sierra Nevada Aquatic Research Laboratory, Star Route 1, Box 198, Mammoth Lakes, CA 93546, U.S.A.
}

\begin{abstract}
Snowmelt lysimeters have been used occasionally to provide a physical measurement for testing models of snowpack energy balance and/or meltwater production. Despite the attractiveness of using records of snowpack outflow for comparison with model results, there are many difficulties with using such data for this purpose. The basic problem is poor correspondence between melt produced at the snow surface and water arriving at the base of the snowpack on a unit-area basis. Unenclosed snowmelt lysimeters allow lateral flow of water into and out of the column of snow overlying the collector. The well-known lateral flow of water in a snowpack allows the effective contributing area at the snowpack surface to be different from the surface area of the collector. Data from several years at two research stations in the Sierra Nevada, California, U.S.A., illustrate the great variability of water flux measured by several collectors. However, the mean of accumulated outflow for a melt season from all the collectors tended to be close to the water equivalence of the overlying snowpack at the onset of snowmelt. Therefore, there is some hope that a set of small snowmelt lysimeters or a few large collectors can adequately sample outflow from the base of the snowpack.
\end{abstract}

\section{INTRODUCTION}

Operational needs of water managers and scientific curiosity have fueled the development of an assortment of models that estimate the production of snowmelt runoff. Throughout the variety of approaches to simulating streamflow in snow-covered regions, the snowmelt portion of the model produces an intermediate result. Although testing and calibration of snowmelt-runoff models is commonly done for the entire model based on reproducing an observed streamflow hydrograph, careful evaluation of components of a model will usually lead to a stronger physical basis of the model, rather than one that seems to work, but for unknown reasons. Even the new generation of computationally complex, spatially distributed snowmelt-runoff models involve development and calibration at the plot scale. Distinguishing between errors from inadequate extrapolation of meteorological variables and errors from inadequate simulation of physical processes has usually required testing at research sites (Davis, 1998).

Testing of hydrologic simulation models has evolved into a distinct specialty within the field of hydrology. A variety of terms describe the different goals of model testing. Here we will follow the conventions of Tesche (1986) and use the term evaluation to mean the process of examining and quantifying the performance of a model.

Evaluation of a point-snowmelt model or the snowmelt component of a basin model has usually been found to be more difficult than assumed while concentrating on the formulation of the model. Real-world constraints have altered, delayed or frustrated many, if not most, attempts at model evaluation. Developing a set of appropriate observations of snowmelt is rarely a trivial exercise. The basic options are determining differences in snowpack water equivalence over time or recording a time series of water release from the base of the snowpack. Various techniques have been used to obtain sequential measurements of snowpack water equivalence, including snow surveys with a gravimetric sampler (Baker and Carder, 1977), snow pillows (Kuusisto, 1979), profiling snow gauges (Tarboton and others, 1995), ultrasonic depth sensors (Kelliher and others, 1996), ablatometers (Lewkowicz, 1985; Munro, 1990) and ablation stakes (LaChapelle, 1959; Kattelmann and others, 1989). The last three methods record only changes in depth and require independent measurements of snow density.

Acquiring time-series measurements of snowpack outflow is the other alternative for creating a basis for model evaluation. Water release from the base of the snowpack is an attractive observation to use for model evaluation because it serves as the output of the snow routine and the input of the runoffgeneration routine. At first glance, it also seems relatively easy to measure. Unfortunately, a variety of physical processes and practical problems make these measurements more involved than casual consideration would suggest.

\section{MODEL EVALUATION WITH DATA FROM LONG- TERM SNOWMELT LYSIMETERS}

Data from snowmelt lysimeters were first used to develop and test models of snowmelt processes during the Cooperative Snow Investigations of the U.S. Army Corps of Engineers and the Weather Bureau following World War II (U.S. Army Corps of Engineers, 1956). The term "snowmelt lysimeter" seems to have been coined during this program as well. Two large (56 and $120 \mathrm{~m}^{2}$ ) snowmelt lysimeters were built at the Central Sierra Snow Laboratory (CSSL) near Lake Tahoe, California, U.S.A., in the early 1950s (Rockwood and others, 1954; Hildebrand, 1957). The lysimeter data from this time period have been used by subsequent generations of modelers searching for good records for testing snowmelt models. In his pioneering paper on energy-balance snowmelt 
modeling, Anderson (1968) stated, "It is difficult to obtain adequate meteorological and snow pack measurements to evaluate fully the reliability of the derived energy-balance equations [for snowmelt]. The only data found of adequate quality were those collected in the Lower Meadow lysimeter studies at the Central Sierra Snow Laboratory." Those early data from the large lysimeter at CSSL have also been used to evaluate models of water transmission through snow (Colbeck, 1979; Marsh and Woo, 1985). Outflow data from a later generation of snowmelt lysimeters at CSSL were used to compare the performance of five different snowmelt models (McGurk, 1985) and to calibrate a modern energy-balance model (Tarboton and others, 1995).

The snowmelt lysimeter at the Weissfluhjoch snow research station of the Swiss Federal Institute for Snow and Avalanche Research has also been used over a long period of time to evaluate models of snowmelt (e.g. Obled and Rossé, 1977; Kustas and others, 1994). A new model, the Snowmelt Numerical-Analytical Package, that combines the energybalance routine of SNTHERM (Jordan, 1991) with an analytical solution for water flow through snow, is under development at the U.S. Army's Cold Regions Research and Engineering Laboratory (Albert and Krajeski, 1998). Data from two snowmelt lysimeters at the Sleepers River Research Watershed in Vermont were used in both event- and season-long evaluations of the model (Albert, 1998; Albert and Krajeski, 1998).

One of the new arrays of snowmelt lysimeters at the Niwot Ridge Long-Term Ecological Research site in the Front Range of Colorado has been used to evaluate a recent model of snowmelt processes (Cline, 1997). Although one of the lysimeters seemed to collect a representative sample of the outflow from the snowpack, the massive quantities of water collected by another lysimeter at the site illustrate some of the inherent difficulties of using snowmelt lysimeters. " $[\mathrm{I}] \mathrm{t}$ measured flow rates an order of magnitude larger than those of lysimeter 1 , and the total volume of water collected was similarly an order of magnitude larger than the volume of water that would have been in the snowpack column above the lysimeter, based on measured snow water equivalence. These discrepancies indicate that the second lysimeter collected water preferentially from a much larger area than just above the lysimeter itself, preventing use of those data here" (Cline, 1997, p. 695).

Archived records from these long-term research sites are a valuable resource for testing refinements of snow models. Anecdotal information from the installers of the equipment is also useful in apprising new users of the data of the specific limitations of snowmelt lysimeters.

\section{MEASUREMENT OF SNOWPACK OUTFLOW}

Snowpack outflow should be distinguished from snowmelt at (or near) the snowpack surface (snow/air interface). Movement of water from the snowpack surface to the snowpack base involves some complex routing and storage processes (e.g. Colbeck, 1977; Wankiewicz, 1979; Marsh, 1991) and is still not fully understood. Snowmelt collectors inserted into the snowpack not far below the surface have a good chance of measuring actual meltwater production, rather than a sample of rerouted water flow. In a study using collectors with an area of $1 \mathrm{~m}^{2}$, amounts of water captured at depths of $<0.4 \mathrm{~m}$ were equal to the calculated melt at the surface (Jordan, 1983). However, another collector of the same

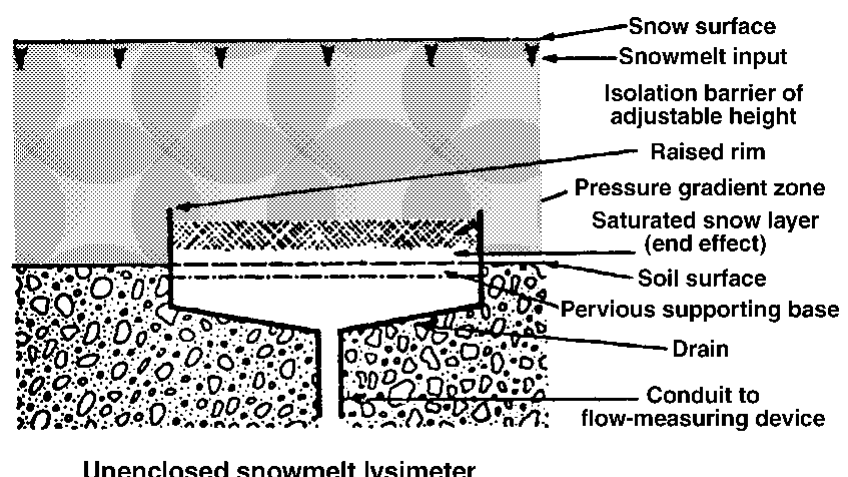

Fig. 1. Features of an unenclosed snowmelt lysimeter.

design inserted at $1 \mathrm{~m}$ below the snow surface intercepted about $50 \%$ more water than was calculated to have been generated at the surface. The difference in these observations results from the complicated pathways that water takes once it leaves the snowpack surface. Meltwater moves both in semi-vertical isolated channels of greater-than-average permeability and along stratigraphic features that impede vertical flow. Preferential flow has been demonstrated in several dye experiments (Gerdel, 1949; Hardy and others, 1992; McGurk and Marsh, 1995; Schneebeli, 1995) that visually illustrate marked variations in vertical meltwater flux across a horizontal plane (Marsh, 1991). Surface meltwater can travel laterally downslope through the pack for many meters before percolating vertically to the base, even in the absence of ice layers (Hardy and others, 1992). The net result of these flow processes is substantial spatial variability in the amount of water released from the base of the snowpack (Kattelmann, 1989).

The fundamental tool for measuring snowpack outflow is a snowmelt lysimeter, which is simply a collector that traps water flowing out of the snowpack, a flow-measuring device and a conduit connecting the two. The two basic types of snowmelt lysimeters are enclosed (where a barrier extends from the base to the snowpack surface, completely isolating the column of snow above the collector) and unenclosed (where a short rim extends $10-50 \mathrm{~cm}$ above the base; see Fig. 1). The enclosed variety would be ideal for testing snowmelt models, because all water produced at the snowpack surface directly over the collector is routed into the collector, and water produced elsewhere is prevented from entering the collector. The contributing area at the snowpack surface is identical with the surface area of the collector. Unfortunately, enclosed snowmelt lysimeters have proven to be very difficult to build and operate. The main problem is to design a barrier that changes height with the snowpack surface and that does not interfere with energy exchange of the snow column being measured. In shallow snow cover, an air gap between the column and surrounding snow that is manually cut (e.g. Gottfried and Ffolliott, 1979) or melted (Albert and Krajeski, 1998) above the rim of the lysimeter is a functional approach to the problem. Adjustable-height sides composed of Styrofoam boards were used around a large collector in Canada (Pysklywec and others, 1968). Plastic film has been used to isolate a small column of snow (Föhn, 1973) and a large mass of disturbed snow (DeWalle and Meiman, 1971) and collect the meltwater. Overcoming the logistical difficulties of maintaining an adequate barrier in deep snowpacks requires new creative thought. 
The default design in snowmelt studies has usually been the unenclosed snowmelt lysimeter. A critical yet often overlooked design feature of unenclosed snowmelt lysimeters is a rim of adequate height (usually $15 \mathrm{~cm}$ ). Because the base of the collector is at atmospheric pressure, the zone above the base in which capillary pressure changes from the average pressure in the pores of the snowpack to zero must be contained within a barrier (Wankiewicz, 1978), otherwise substantial quantities of water will not enter the collector. During the last few days of the snowmelt season, an unenclosed snowmelt lysimeter functions as an enclosed type, after the snow depth decreases below the height of the rim. At this point, one can be confident that outflow is a good measure of snowmelt.

Various investigators have been frustrated by the logistical difficulties of capturing water flowing through a snowpack. Dozens of studies that employed snowmelt lysimeters have been reviewed, and complaints such as "the meltwater wave apparently reached the [lysimeter] before it left the surface" or "lysimeter failed to collect any water until the snowpack had almost disappeared" were not uncommon. An assortment of theoretical and practical considerations for snowmelt-lysimeter design can be found in Kattelmann (1984). Beyond the lag and attenuation of the surface-melt signal caused by routing through the snowpack, the plumbing system can create additional delays. Lag and storage in the collector and pipes should be tested by adding known volumes of water to the system under controlled conditions. If the time-step of the model evaluation is daily, then both the routing considerations in the model and the actual lags in the physical system can be largely neglected, at least once the snowpack is actively releasing water. There can be significant delays between melt and outflow at the onset of melt, which remains an area of research. Heating of the plumbing system at the beginning of the snowmelt season may be necessary to avoid any artificial delays in water release into the measuring device caused by freezing within the pipes.

Over the past half-century, substantial experience has been gained with snowmelt lysimeters, but with limited documentation of successes and failures. Designers of new installations should consult available literature and users of snowmelt lysimeters for critical details, but they should also experiment with fresh approaches. If the ideal situation can be found, natural runoff plots on impermeable surfaces with distinct contributing areas could serve as a highly effective basis for evaluations of snowmelt models. Snowmelt runoff from such "natural lysimeters" would provide a conceptually better basis for evaluating output from snowmelt models than the somewhat artificial sampling of snowpack outflow by snowmelt lysimeters. However, locating and instrumenting an ideal natural situation presents a range of other logistical problems.

\section{OBSERVATIONS OF OUTFLOW VARIABILITY}

Until the mid-1980s, very little information was available about variations in the flow field within the snowpack. The dye-tracing studies mentioned above suggested that flow was far from uniform, but replicate measurements of snowpack outflow were lacking. The first report regarding measurements of variations in flow that this author is aware of involved the insertion of three collectors of $1 \mathrm{~m}^{2}$ area and five collectors of $1.1 \times 10^{-3} \mathrm{~m}^{2}$ area into a snowpack at depths of 1.5 and $0.6 \mathrm{~m}$ below the surface, respectively (Wankiewicz, unpublished). Meltwater flow captured by these two sets of collectors over periods of $<12$ hours had coefficients of variation (standard deviation/mean) averaging 0.52 for the larger collectors and 0.66 for the smaller ones. Differences in average daily outflow collected by a pair of lysimeters of $4.5 \mathrm{~m}^{2}$ area at two sites in Norway were $<1 \mathrm{~mm}$ (average melt rate about $15 \mathrm{~mm}$ ). Differences between seasonal totals of outflow and the sum of snowwater equivalence, rainfall and estimated condensate were $<10 \%$ in each of the 3 years of this same study (Harstveit, 1984). Snow depths were $<1 \mathrm{~m}$ at this study location.

A study in the Canadian High Arctic compared outflow captured with a $1 \mathrm{~m}^{2}$ lysimeter and outflow captured with two small collectors of $0.25 \mathrm{~m}^{2}$ area (Marsh and Woo, 1985). There was $<10 \%$ variation in the daily volumes collected with this set of lysimeters. One of these $0.25 \mathrm{~m}^{2}$ collectors was divided into 16 compartments of equal area that were measured independently. Daily volumes from these small cells varied from $0 \%$ to $240 \%$ of the mean from the entire area (Marsh and Woo, 1985). This same device was later used in a study of snow chemistry. In this application, the daily volumes varied from $25 \%$ to $300 \%$ of the mean. Concentrations of solutes in the meltwater were also found to be highly variable (Marsh and Pomeroy, 1993). In another study of snow chemistry, the total seasonal outflow from a snowmelt lysimeter of $5 \mathrm{~m}^{2}$ area was found to be equal to the sum of peak snowwater equivalence and rain during the melt period (Barry and Price, 1987). However, the mean of the total seasonal outflow from a set of six collectors, each with an area of $5 \times 10^{-2} \mathrm{~m}^{2}$, was more than twice the output of the large lysimeter.

Outflow from a set of four snowmelt lysimeters, each with an area of $6 \mathrm{~m}^{2}$, at CSSL has been examined previously for three melt seasons (Kattelmann, 1989). Two of these collectors were subdivided into thirds, with independent plumbing and measurement systems. For three of the large snowmelt lysimeters, monthly volumes were generally similar, and annual volumes for 1986 and 1987 were within $15 \%$ of each other. However, volumes collected by the other lysimeter were much greater than the mean of these three. Microtopographic effects were believed to be responsible for this difference. Outflow from the six $2 \mathrm{~m}^{2}$ subdivisions exhibited greater variability than that from the larger collectors. The standard deviation of daily flow amounts collected over the $2 \mathrm{~m}^{2}$ areas often exceeded the mean when flows exceeded $10 \mathrm{~mm} \mathrm{~d}^{-1}$. Variability of outflow was greatest during rain-on-snow events. Coefficients of variation for monthly totals of outflow ranged from 0.1 to 1.1 and usually exceeded 0.4 (Kattelmann, 1989).

Variability in snowpack outflow has also been examined on Niwot Ridge in the Front Range of Colorado, U.S.A. (Rikkers and others, 1996). Here, 16 small snowmelt lysimeters, each $0.2 \mathrm{~m}^{2}$ in area, were located in a circular array with a $5 \mathrm{~m}$ radius, with the collectors $2 \mathrm{~m}$ apart. Measured outflow varied greatly between some collectors. Outflow from three of the collectors (located in a minor topographic depression) exceeded measurement capacity and greatly exceeded snowpack water equivalence, while total seasonal outflow from three others was only $5 \%$ of the snowpack water equivalence. The total volume of water collected by all 16 lysimeters over the season was 400 times greater than the equivalent depth of water stored as snowpack over the surface area of the lysimeters. Calculations of effective contributing area ranged from 0.001 to $38 \mathrm{~m}^{2}$. 


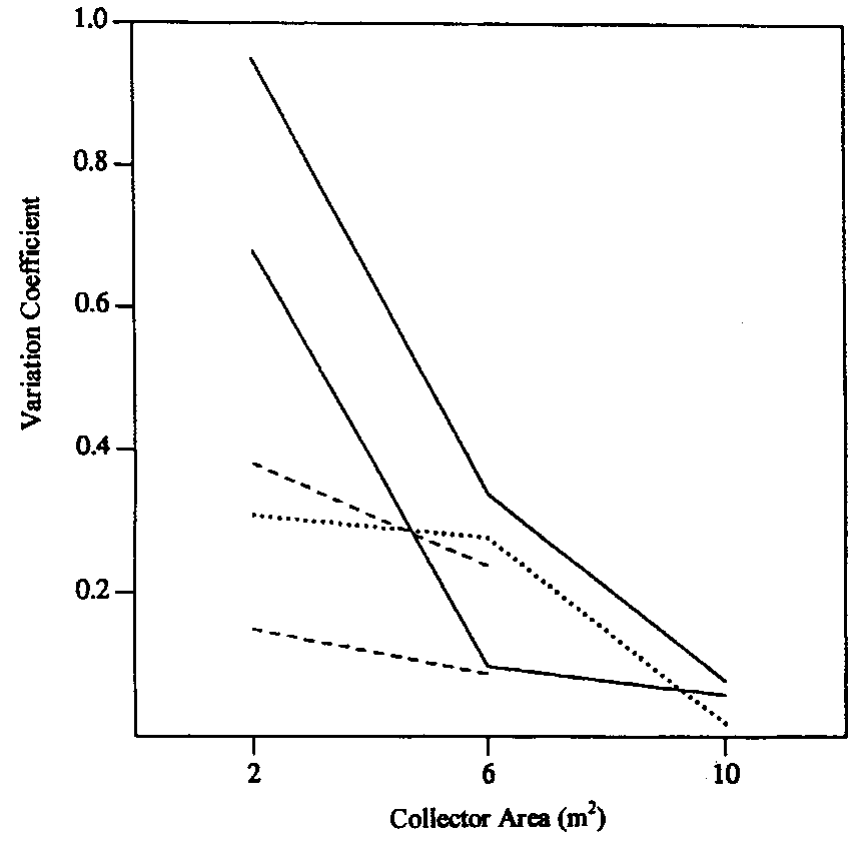

Fig. 2. Variability in snowpack outflow declines rapidly with increases in collector area over the range $2-10 \mathrm{~m}^{2}$. Each curve is from a different year.

Recent studies at Mammoth Mountain in the Sierra Nevada, California, have provided additional information about the variability of snowpack outflow (Harrington and Bales, 1998). This research site at $2900 \mathrm{~m}$ a.s.l. had up to eight (depending on the year) snowmelt lysimeters, each $1 \mathrm{~m}^{2}$ in area with a $0.2 \mathrm{~m}$ high rim, which were arranged in two groups of four, about $20 \mathrm{~m}$ apart. Outflow from individual collectors ranged from $20 \%$ to $200 \%$ of the mean from all collectors. Coefficients of variation for total seasonal outflow were $0.2-0.7$. Nevertheless, the mean of the cumulative outflow over intervals between measurements of snowpack water equivalence closely matched the corresponding changes in water equivalence.

Additional data are now available from the CSSL lysimeters for the years 1987-92, including data from two large collectors of $10 \mathrm{~m}^{2}$ area. Between the different years, coeffi-

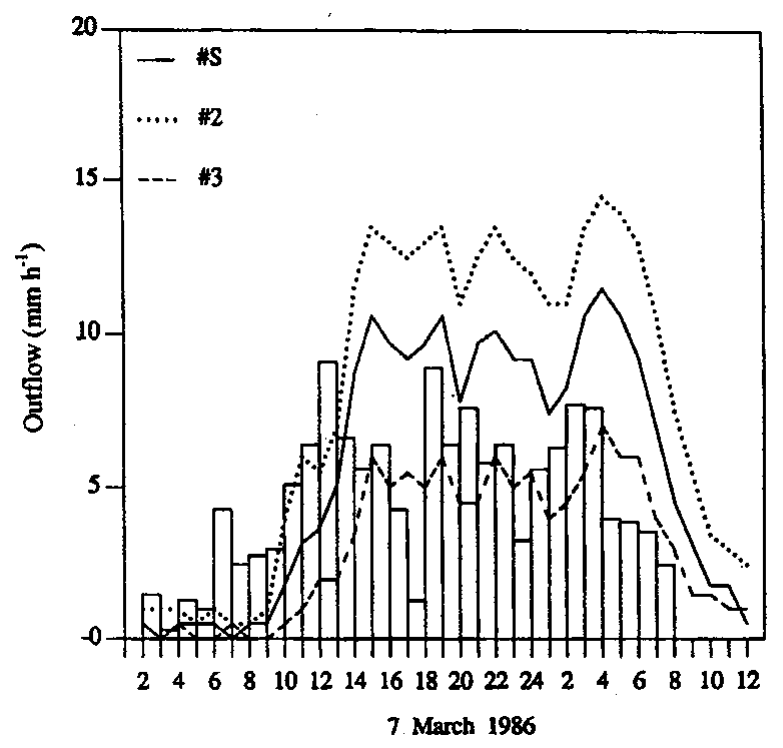

Fig. 3. Example of outflow variability during rain-on-snow. cients of variation of outflow were $0.1-1.0$ for the $2 \mathrm{~m}^{2}$ collectors, $0.1-0.3$ at $6 \mathrm{~m}^{2}$ and $0.02-0.08$ at $10 \mathrm{~m}^{2}$ (Fig. 2). Monthly total outflows from the $10 \mathrm{~m}^{2}$ collectors were generally within $4 \%$ of each other. During 1988, however, well-developed ice layers apparently diverted much of the meltwater away from one of the large collectors until melt removed the obstructions to vertical flow. The availability of a second large collector both provided a continuous record for the season and helped diagnose the problem with the other collector. The variability at all size scales is much greater on a daily basis, and especially during rain-on-snow events (Fig. 3). During some rain-on-snow events at CSSL, total outflow has differed by more than an order of magnitude between collectors with largest and smallest response.

The network of channels and layers within snow cover can produce substantial differences in outflow from the base of the snow pack at the scale of a few square meters. As collection area is increased, a point should be reached where there is sufficient averaging of the flow field to produce consistent results between multiple snowmelt lysimeters. In a few cases, relatively uniform flow has been observed over areas of $<1 \mathrm{~m}^{2}$. Nevertheless, the likelihood of inflow balancing outflow within the snow column above the collector increases with area. New results from CSSL suggest that the representative area for uniform flow conditions is $>10 \mathrm{~m}^{2}$ for deep snowpacks. A rule of thumb suggests that the flow of water is uniform over areas greater than the square of the snowpack depth (Male and Gray, 1981). The measurements summarized above suggest this concept is still reasonable.

\section{CONCLUSIONS}

The variability in snowpack outflow over the relatively small areas ( $2 \mathrm{~m}^{2}$ or less) common among unenclosed snowmelt lysimeters can be problematic for modelers seeking data for use in evaluating snowmelt models. Users of outflow data should be aware of the limitations of the measurement techniques and the sampling design. If new installations are contemplated, the potential variability in outflow should be given thorough consideration. When the area of a collector is limited to 1 or $2 \mathrm{~m}^{2}$, several snowmelt lysimeters should be deployed at one site to adequately sample the flow field. Even when collectors of $10-20 \mathrm{~m}^{2}$ area are used, a minimum of three should be installed to assess the variability and provide multiple sources of data. Because gaps in the outflow record can cripple the utility of the measurements, redundancy and independence in the measurement and recording systems are recommended. In addition, representative measurements of snowpack water equivalence every few days allow a comparison between outflow and cumulative ablation. A creative design for an enclosed snowmelt lysimeter that is easy to operate and does not influence the energy balance of the enclosed snow column is still needed.

As models of snowmelt processes continue to be refined, there will be a continuing need for good data to test them. Evaluating the snowmelt component of complex basin-wide models requires information from index plots to isolate the basic energy-balance aspects of the model. Snowmelt lysimeters have the potential to provide data on snowpack outflow suitable for testing models at a point. Caution is necessary when using outflow data collected by others for other purposes. 


\section{ACKNOWLEDGEMENTS}

An evaluation of the physical hydrology of the Sierra Nevada was supported by the NASA Earth Observing System program through a grant to J. Dozier at the University of California, Santa Barbara. I am grateful to R. Osterhuber and B. McGurk at CSSL and R. Harrington at Mammoth Mountain for their help with maintaining the snowmelt lysimeters. Their insights regarding interpretation of the data are also appreciated.

\section{REFERENCES}

Albert, M. R. 1998. Using an analytical solution to model a season of snowmelt. [Abstract.] CRREL Spec. Rep. 98-10, 96.

Albert, M. and G. Krajeski. 1998. A fast, physically based point snowmelt model for use in distributed applications. Hydrol. Processes, 12, 1809-1824.

Anderson, E. A. 1968. Development and testing of snow pack energy balance equations. Water Resour. Res., 4(1), 19-37.

Baker, M. B., Jr and D. R. Carder. 1977. Comparative evaluations of four snow models. Proc. West. Snow Conf., 45th Annual Meeting, 18-21 April 1977, Albuquerque, New Mexico, 58-62.

Barry, P. J. and A. G. Price. 1987. Short term changes in the fluxes of water and of dissolved solutes during snowmelt. In Jones, H. G. and W. J. Orville-Thomas, eds. Seasonal snowcovers: physics, chemistry, hydrology. Dordrecht, etc., D. Reidel Publishing Co., 501-530. (NATO ASI Series C: Mathematical and Physical Sciences 211.

Cline, D.W. 1997. Snow surface energy exchanges and snowmelt at a continental, midlatitude Alpine site. Water Resour. Res., 33(4), 689-701.

Colbeck, S. C. 1977. Short-term forecasting of water run-off from snow and ice. f. Glaciol., 19(81), 571-588.

Colbeck, S. C. 1979. Water flow through heterogeneous snow. Cold Reg. Sci. Technol., 1(1), 37-45.

Davis, R. E. 1998. A review of spatially distributed modeling of snow. [Abstract.] CRREL Spec. Rep. 98-10, 29.

DeWalle, D. R. and J. R. Meiman. 1971. Energy exchange and late seasonal snowmelt in a small opening in a Colorado subalpine forest. Water Resour. Res., 7(1), 184-188.

Föhn, P. M. B. 1973. Short-term snow melt and ablation derived from heatand mass-balance measurements. F. Glaciol., 12(65), 275-289.

Gerdel, R.W. 1949. Evaluation of snow cover distribution from horizontal photographs. San Francisco, CA, U.S. Army Corps of Engineers. (Cooperative Snow Investigations Progress Report, Misc. Rep. 1.)

Gottfried, G. J. and P. F. Ffolliott. 1979. An evaluation of snowmelt lysimeters in an Arizona mixed conifer stand. Hydrol. Water Res. Arizona SW9, 221-229.

Hardy, J. P., M. R. Albert and D. R. Hardy. 1992. Variability in snowmelt routing. [Abstract.] EOS, 73(43), Supplement, 174.

Harrington, R. F. and R. C. Bales. 1998. Interannual, seasonal, and spatial patterns of meltwater and solute fluxes in a seasonal snowpack. Water Resour. Res., 34(4), 823-831.

Harstveit, K. 1984. Snowmelt modelling and energy exchange between the atmosphere and a melting snow cover. Bergen, University of Bergen. Geophysical Institute. (Scientific Report 4.)

Hildebrand, C. E. 1957. Lysimeter studies of snowmelt. Proc. West. Snow Conf., 25th Annual Meeting, November 1957, Fort Collins, Colorado, 94-105.

Jordan, P. 1983. Meltwater movement in a deep snowpack. 2. Simulation model. Water Resour. Res., 19(4), 979-985.

Jordan, R. 1991. A one-dimensional temperature model for a snow cover: technical documentation for SNTHERM.89. CRREL Spec. Rep. 91-16.

Kattelmann, R. C. 1984. Snowmelt lysimeters: design and use. Proc. West. Snow Conf., 52nd Annual Meeting, 17-19 April 1984, Sun Valley, Idaho, 68-79.

Kattelmann, R. 1989. Spatial variability of snow-pack outflow at a site in Sierra Nevada, U.S.A. Ann. Glaciol., 13, 124-128.

Kattelmann, R., K. Elder and J. Dozier. 1989. Monitoring basin-wide snowmelt with ablation stakes. In A merging of theory and practice. Proceedings of the International Snow Science Workshop, 12-15 October 1988, Whistler, B.C. Vancouver, B.C., Canadian Avalanche Association, 259-261.
Kelliher, F. M., I. F. Owens, A. P. Sturman, J. N. Myers, J. E. Hunt and T. M. McSeveny. 1996. Radiation and ablation on the neve of Franz Josef Glacier. 7. Hydrol. (N. Z.), 35(1), 129-148.

Kustas, W. P., A. Rango and R. Uijlenhoet. 1994. A simple energy budget algorithm for the snowmelt runoff model. Water Resour. Res., 30(5), 1515-1527.

Kuusisto, E. 1979. Optimal complexity of a point snowmelt model. In Colbeck, S. C. and M. Ray, eds. Modeling of Snow Cover Runoff, 26-28 September 1978, Hanover, New Hampshire. Proceedings. Hanover, NH, U.S. Army Corps of Engineers. Cold Regions Research and Engineering Laboratory, 205-210.

LaChapelle, E. 1959. Errors in ablation measurements from settlement and sub-surface melting. f. Glaciol., 3 (26), 458-467.

Lewkowicz, A. G. 1985. Use of an ablatometer to measure short-term ablation of exposed ground ice. Can. F. Earth Sci., 22(12), 1767-1773.

Male, D. H. and D. M. Gray. 1981. Snowcover ablation and runoff. In Gray, D. M. and D. H. Male, eds. Handbook of snow: principles, processes, management and use. Toronto, Ont., Pergamon Press Canada Ltd., 360-436.

Marsh, P. 1991. Water flux in melting snow covers. In Corapcioglu, M.Y., ed. Advances in porous media.Vol.1. New York, Elsevier Science Publishers, 61-124.

Marsh, P. andJ.W. Pomeroy. 1993. The impact of heterogeneous flow paths on snowmelt runoff chemistry. Proc. East. Snow Conf., 50th Annual Meeting, 8-10 June 1993. Québec, Que., Canada, 231-238.

Marsh, P. and M.-K. Woo. 1985. Meltwater movement in natural heterogeneous snow covers. Water Resour. Res., 21 (11), 1710-1716.

McGurk, B. J. 1985. Five snowmelt models: a comparison of prediction accuracy. Proc. West. Snow Conf., 53rd Annual Meeting, 16-18 April 1985, Boulder, Colorado, 171-174.

McGurk, B. J. and P. Marsh. 1995. Flow-finger continuity in serial thick-sections in a melting Sierran snowpack. International Association of Hydrological Sciences Publication 228 (Symposium at Boulder 1995 - Biogeochemistry of Seasonally Snow-Covered Catchments), 81-88.

Munro, D. S. 1990. Comparison of melt energy computations and ablatometer measurements on melting ice and snow. Arct. Alp. Res., 22 (2), 153-162.

Obled, C. and B. Rossé. 1977. Mathematical models of a melting snowpack at an index plot. 7. Hydrol., 32(1/2), 139-163.

Pysklywec, D.W., K. S. Davar and D. I. Bray. 1968. Snowmelt at an index plot. Water Resour. Res., 4(5), 937-946.

Rikkers, M. F., M.W. Williams and R. A. Sommerfeld. 1996. Spatial variance of snowmelt at a continental alpine site. Proc. West. Snow Conf., 64th Annual Meeting, 16-18 April 1996, Bend, Oregon, 23-31.

Rockwood, D. M., P. B. Boyer and C. E. Hildebrand. 1954. Lysimeter studies of runoff from a deep snow pack. International Association of Scientific Hydrology Publication 39 (General Assembly of Rome 1954 - Snow and Ice), Vol. 4, 137-165.

Schneebeli, M. 1995. Development and stability of preferential flow paths in a layered snowpack. International Association of Hydrological Sciences Publication 228 (Symposium at Boulder 1995 - Biogeochemistry of Seasonally Snow-Covered Catchments), 89-95.

Tarboton, D. G., T. G. Chowdhury and T. H. Jackson. 1995. A spatially distributed energy balance snowmelt model. International Association of Hydrological Sciences Publication 228 (Symposium at Boulder 1995 - Biogeochemistry of Seasonally Snow-Covered Catchments), 141-155.

Tesche, T.W. 1986. Theoretical basis and performance evaluation of current snowmelt-runoff simulation models. In Kane, D. L., ed. Symposium: Cold Regions Hydrology, 22-25 July 1986, Fairbanks, Alaska. Proceedings. Bethesda, MD, American Water Resources Association, 449-459. (AWRA Technical Publication Series TPS-86-1.)

United States Army Corps of Engineers. 1956. Snow hydrology: summary report of the snow investigations. Portland, OR, U.S. Army Corps of Engineers. North Pacific Division.

Wankiewicz, A. 1978. Hydraulic characteristics of snow lysimeters. Proc. East. Snow Conf., 35th Annual Meeting, 2-3 February 1978. Hanover, NH, U.S.A., 105-116.

Wankiewicz, A. 1979. A review of water movement in snow. In Colbeck, S. C. and M. Ray, eds. Modeling of Snow Cover Runoff, 26-28 September 1978, Hanover, New Hampshire. Proceedings. Hanover, NH, U.S. Army Corps of Engineers. Cold Regions Research and Engineering Laboratory, 222-252.

Wankiewicz, A. Unpublished. Variability of flow within ripe snowpacks. Ottawa, Ont., Environment Canada. National Hydrology Research Institute. 